\title{
Ethics of Tax Evasion: Evidence from Self-employed Tax-payers' of Dessie Town Administration, Ethiopia
}

\author{
Muleye Tarekegn \\ Department of Accounting and Finance, Wollo University, Ethiopia
}

Copyright $(\mathcal{C} 2015$ by authors, all rights reserved. Authors agree that this article remains permanently open access under the terms of the Creative Commons Attribution License 4.0 International License

\begin{abstract}
Tax evasion in most developing countries is so widespread and development is much exacerbate by the fact that not many of these countries have made an effort to measure the ethical reasons that taxpayers give. This study, therefore, is designed to describe the ethics tax evasion in Dessie town administration, Ethiopia by taking evidence from 336 randomly selected self-employed taxpayers through a 7 point likert scale questionnaire. Accordingly, this study result shows that tax evasion is ethical in certain situations, and sometimes it is unethical in some other situations. The top mean score ranked arguments that taxpayers gave to justify tax evasion include government corruption, unfair tax system, government discrimination against political affiliation, tax un-affordability, when the money collected is wasted, and high tax rate. In contrary, tax evasion is not ethical when most of the money collected is spent wisely, if the money collected is spent on worthy projects, when the money collected is spent on projects that do benefit taxpayers, and when the money collected is spent on projects that do not benefit taxpayers. The other finding of this study is that the ethics of tax evasion is different among gender, as well as over academic status of the respondents. Females oppose tax evasion than male i.e. females are more ethical than male. Likewise, educated are more ethical than uneducated, this is with the view that tax evasion is unethical. In general, the overall finding of this study indicated that the government should aware the taxpayers that there is proper administration, fair tax system and money collected are spent wisely.
\end{abstract}

Keywords Ethics, Tax Evasion, Gender, Education Status, Self-employed Taxpayers

\section{Introduction}

Much of the failure to finance development spending particularly the failure of wealthy donor countries to provide promised increases in aid budgets- is a failure of political will. But states in the Majority World are unable to sustain their own spending on health, education and infrastructure substantially because they cannot raise adequate revenues for social spending themselves $[1,9]$. Likewise, it has the effect of distorting the principle of perfect market resource allocation with rippling effects on the state of infrastructures [2]. There is no doubt that revenue due in any government will be reduced by the unpatriotic act of tax evaders thereby affecting economic growth [3].

Literature in accounting and finance has argued that there is drastic reduction in States budget all over the world because of the practice of tax evasion by economic agents [4]. The amount of revenue losses resulting from tax evasion is potentially enormous in any economy [5]. In most developing countries, like Ethiopia, the revenue generated by the government is quite less than the expenditures spent. The country's tax mobilization was also the lowest among most African countries and thus, identifying the factors that determine tax compliance behavior has been open for empirical investigation [6]. This low revenue yield of taxation can be attributed to the fact that tax provisions are not properly enforced either on account of the inability of administration or on account of straight forward collusion between the tax administration and taxpayers [7]. Moreover, a major challenge for many African governments is to establish an accountability relation between the levying of taxes, fees and charges and the supply of public goods and services [8] - How this contributes to taxpaying decision of the taxpayer? Hence, although taxpayers' tax evasion is a continual and growing global problem [9], studies suggest that developing countries, many of them in Sub-Saharan Africa, are the hardest hit [10].

Tax evasion in most developing countries is so rampant and this development is much exacerbate by the fact that not many of these countries have made an effort to measure the ethical reasons that taxpayers give and the extent of this problem [2]. Scholars argued on the need of understanding the ethics of tax evasion by taxpayers that when required revenue for smooth operation cannot be raised, countries often times resort to increase tax rates or borrowings which may not only crowd out the private sector of their economies but also lead them to debt traps. On the other hand, tax 
evasion has the effect of distorting the principle of perfect market resource allocation and income redistribution. This can lead to economic growth stagnation and far much reaching socio-economic repercussions. Thus, there is the need to understand the behavior of taxpayers and the reasons that cause such specific behavior. In other to ensure that adequate revenue is generated for the government and subsequent provision of sufficient infrastructure and necessary amenities, it is important to know the attitudes of the citizenry towards the collection of taxes [11,2].

Therefore we can understand that tax evasion is a complex phenomenon that can be overcome by bringing changes in social and moral behavior [12]. Understanding the taxpayers' ethics of tax evasion is also essential struggle the evasion behaviour because persons who perceive tax evasion as an ethical issue are less likely to evade regardless of the situation than persons who do not [13]. Moreover, Karlinsky, Burton, \& Blanthorne [34] indicated that perception of tax evasion as a non-serious crime has led to an environment where taxpayers may not be afraid of evading tax. Hence, Chiumya [11] noted the need of taxpayers' tax evasion perception in one country that curbing tax evasion is one of the most complex activities in tax administration due to the fact that tax evasion takes many forms and facets. Thus, one of the major keys to successfully reduce tax evasion activities is to first and foremost understand the behavior of taxpayers and the reasons that cause such specific behaviour.

Importantly, the numerous researches that have been done about tax evasion have been written from the perspective of public finance. They discuss technical aspects of tax evasion and the primary and secondary effects that tax evasion has on an economy. In many cases there is also a discussion about how to prevent or minimize tax evasion. However, very few articles discuss ethical aspects of tax evasion. Most studies on tax evasion look at the issue from a public finance or economics perspective, although ethical issues may be mentioned briefly, in passing $[14,2,15]$. Moreover, ethical aspect of tax evasion was not discussed too much specifically by taking evidence on tax ethics from developing countries [16]. Little is, therefore, known about general tendencies of tax evasion ethics in Ethiopia. Thus, there is a need for further research, which the present study is intended to partially address. Moreover, prior ethics of tax evasion researches, even using the same survey instrument, suggest more that more research is needed to determine the issues of tax evasion among other countries $[13,2,8,15]$.

The taxpayers' attitude on tax evasion is differing from one country to another and also from one individual to another [17], due to factors, like taxpayers perceptions of the tax system and revenue authority; peer attitude/ subjective norms; taxpayers understanding of the tax system; probability of detection and many other factors [18]. Furthermore, Roth, Scholz and Dryden-Witte (1989) as cited in Uadiale et al, [19] claim that the various cultural contexts which shape a person's interpretation of events influences taxpayers attitude toward tax evasion. Taxpayers' perception of tax evasion is different among countries [20]. Therefore, it can be concluded that, the different regions will have the different opinions regarding tax evasion. Cultural differences are one of the factors that affect an individual moral decision making or influence their perception regarding ethics on tax evasion. As a result one end of spectrum, a few studies concluded tax evasion is never justified. On the other hand of spectrum, several studies concluded that tax evasion could be ethical in certain situation [16].

Hence, this study was interested to study the perception of taxpayers on tax evasion in Ethiopian context particularly in Dessie town administration setting to determine the justification of tax evasion by taxpayers. In fact, in addition to examining the tax evasion perception of taxpayers in Ethiopian setting this study has also determined the severity of tax evasion in the study area by investigating the existence of factor that taxpayers uses to justify tax evasion. To the best of researcher's knowledge, no prior empirical study has been found that investigates the issue of the ethics of tax evasion in this area.

\subsection{Objective of the Study}

- To identify Dessie town administration taxpayers' perceptual reasons for tax evasion

- To investigate the perception of Dessie town administration taxpayers to the payment of taxes on ethical reason

- To identify specific key areas that Dessie town administration taxpayers link to tax evasion

- Describe the ethics of tax evasion in different demographic characteristics of self-employed taxpayers?

\subsection{Significance of the Study}

Tax has gained importance not only as a tool for raising revenue but also help to meet the administrative costs of governance, the provision of public services, and also as a tool available to planners, policy makers and implementers aiming to regulate the economy in order to bring about desired economic development especially in developed countries $(21,22]$. So tax has to be effectively administered. Hence, to contribute its own for it, this study has various importance for different bodies. In the first place, it helps the tax authorities of Dessie town administration as well as the government in general to understand the perception of Dessie town taxpayers about ethics of tax evasion which will help in turn to identify the core reasons of tax evasion in the town. Therefore, secondly, it provides policy implications for the government as well as the tax collection authority. Thirdly, since the study investigated the taxpayers' perceptual reasons of tax evasion it can have also an importance on identifying tax obligation awareness gaps of taxpayers, which can be future training area to minimize tax evasion. In the fourth place, since, though there are cultural and other differences for tax compliance, prior researches less emphasized on developing countries setting to evaluate 
the ethics of tax evasion, this study, therefore, peculiarly contributes in filling literature gaps by analyzing the ethics of tax evasion in developing countries particularly in Ethiopian context. Finally, it also provides an initiation for those potential researchers who are interested to conduct a detailed and comprehensive study regarding the tax evasion in Ethiopia. It can also serves as a reference point for future researchers and students.

\subsection{Scope of the Study}

The study analyzed the tax evasion perception of taxpayers in Ethiopia with special reference of Dessie town Administration. In particular, the tax evasion perception of only self-employed taxpayers has been considered in this study because there is evidence to study in emphasis that individuals enter into self-employment to exploit the tax evasion opportunities therewith associated [23]. Moreover, self-employed individuals often have the option of evading some or all of their tax liability [15]. Moreover, due to time and financial constraints among other factors this study was delimited only to Dessie town administration self-employed taxpayers, who are only natural persons currently working at Dessie town.

\section{Research Methodology}

\subsection{The Research Design}

The purpose of this study is to describe the perception of business profit taxpayer about tax evasion. Hence, a descriptive survey research design was used in this study which best achieve the set research objective because such research strategy was considered necessary for this study objective is because of its ability to view comprehensively and in detail the major questions raised in the study. According to Denscombe [24], this research design is an efficient way of collecting information from a large number of respondents and the ability to use statistical techniques to determine statistical significance.

\subsection{Source of Data}

Since this study is designed to examine business income taxpayers' perception on ethics of tax evasion as well as their feelings on the seriousness of factors which drives their perception of tax evasion like corruption, tax rate etc, data for this study was collected from only primary source of data through structured questionnaire that can help to gather their opinion.

\subsection{Population of the Study}

Though the tax evasion opinions of different segments of the society have to be examined, this study is designed to investigate the part from the total segments of the society which is about the tax evasion perception of self-employed individual taxpayers. Since, the population of this study is the self-employed individual taxpayers of Dessie town administration. According to Dessie town tax collection authority (2015), they are estimated to be 10, 820 registered individuals in number in this year.

\subsection{Sample Size and Sampling Technique}

From the above total population 336 samples were drawn. Then these determined samples were selected through simple random sampling technique from the population. The taxpayers' registration list in the Dessie town tax collection center was taken as sampling frame.

\subsection{Data Collection Technique}

The necessary data to achieve the set research objective were collected through distributing close ended questionnaire to self-employed taxpayers in Dessie town administration to express their opinions about tax evasion. After reviewing the recent different literatures $[2,14,15,16$, $20,25]$ which are done on ethics of tax evasion in other countries, a questionnaire is developed that incorporates all the major issues that have been discussed in the literatures except some contextualization. Since the questionnaires are similar on previous researches done across countries, the analysis result of this data allowed for cross country comparisons and the range of tax variables permits testing the relevance of the various theories about taxpayer tax evasion perception.

\subsection{Data Analysis Technique}

Descriptive statistics were recruited to describe the tax evasion ethics of self-employed tax payers. 
Table 1. Demographic Profile of Respondents

\begin{tabular}{|c|c|c|c|c|c|}
\hline 1 & Sex of respondents & Frequency & Percent & Valid Percent & Cumulative Percent \\
\hline & male & 228 & 67.9 & 69.1 & 69.1 \\
\hline & female & 102 & 30.4 & 30.9 & 100.0 \\
\hline & Total & 330 & 98.2 & 100.0 & \\
\hline \multirow[t]{7}{*}{2} & Age group of the respondents & Frequency & Percent & Valid Percent & Cumulative Percent \\
\hline & below 25 & 66 & 19.6 & 20.0 & 20.0 \\
\hline & $26-35$ & 156 & 46.4 & 47.3 & 67.3 \\
\hline & $36-45$ & 72 & 21.4 & 21.8 & 89.1 \\
\hline & $46-55$ & 24 & 7.1 & 7.3 & 96.4 \\
\hline & above 56 & 12 & 3.6 & 3.6 & 100.0 \\
\hline & Total & 330 & 98.2 & 100.0 & \\
\hline \multirow[t]{7}{*}{3} & Academic status of the respondents & Frequency & Percent & Valid Percent & Cumulative Percent \\
\hline & grade 8 and below & 54 & 16.1 & 16.4 & 16.4 \\
\hline & $9-10 / 12$ complete & 126 & 37.5 & 38.2 & 54.5 \\
\hline & Diploma & 90 & 26.8 & 27.3 & 81.8 \\
\hline & Degree & 54 & 16.1 & 16.4 & 98.2 \\
\hline & Masters & 6 & 1.8 & 1.8 & 100.0 \\
\hline & Total & 330 & 98.2 & 100.0 & \\
\hline \multirow[t]{6}{*}{4} & Respondents Experience in their current business & Frequency & Percent & Valid Percent & Cumulative Percent \\
\hline & year in business $<=5$ & 114 & 33.9 & 40.4 & 40.4 \\
\hline & years in business 6-10 & 132 & 39.3 & 46.8 & 87.2 \\
\hline & years in business $11-15$ & 24 & 7.1 & 8.5 & 95.7 \\
\hline & years in business $>16$ & 12 & 3.6 & 4.3 & 100.0 \\
\hline & Total & 282 & 83.9 & 100.0 & \\
\hline
\end{tabular}

\section{Data Analysis and Discussion}

\subsection{Demographic Profile of Respondents}

Both male and female self-employed individuals were participated in this study. Tables 1 , shows that most of the respondents $(69.1 \%)$ were male taxpayers, and the remaining respondents were female $(34.6 \%)$. The table result shows that, though male and female proportion is not also equal in the population, relatively both sex of business individuals are incorporated in this study which help in describing the perception of taxpayers about tax evasion in respect with different sex.

Participants of this study were taken from different age groups in a certain proportion. Table 1 indicates that most of the respondents which comprises of $47.3 \%$ were from the age group between $26-35$ years old followed by respondents under age group of 36-45 years and below 25 year old that have a proportion of $21.8 \%$ and $20 \%$ from the total respondent, respectively. The remaining $7.3 \%$ of respondents are from age group 46-55 and 3.6\% are age above 56 . The above age groups of the respondents indicated that the respondents of this study were in the good age group to make informed decisions for the data they are provided for this study.
The respondents of this study have different educational levels. Table 1 indicated that about $16.4 \%$ of survey respondents have academic status below grade eight, while majority of the respondents are 9-10/12 grade complete and diploma holder with $38.2 \%$ and $27.3 \%$ proportion from the total respondent, respectively. The remaining $16.4 \%$ respondents are masters' degree holder.

These academic status of the respondents revealed that, though respondents have different educational status, they had no problems in responding to the questionnaire. The compositions of respondents in different educational status have also significance to describe the justification of respondents about tax evasion in different educational level of taxpayers.

In terms of years of experience in current business respondents are working in, $40.4 \%$ of the survey respondents have worked 5 years and less, where as $46.8 \%$ of the respondents have worked 6-10 years in their current business. The remaining few respondents which comprises of $8.4 \%$ and $4.3 \%$ from the total respondents have worked in their current business for 11-16 years, and more than 16 years respectively. This age proportion implies that participants of this study have some taxpaying experience in their business. Hence they responded for the questionnaires of this study based up on their experience of taxation in the town i.e. their 
responses were a reflection of their experiences. It helps just to describe the perception of taxpayers about tax evasion.

\subsection{Mean Score of the Respondents Perception about Tax Evasion}

Taxpayers give different weight to the different situation stated in the 18 statements for their justification of tax evasion behavior. Hence, the table below reported the mean score of each statement.

As indicated in Table 2, it shows the 18 statements which reflect the possible justification of taxpayers to evade tax, and show the mean scores for each statement. Though respondents do have different mean scores for those different statements as indicated in the table, the mean score for all 18 statements was 3.8960 , which, on a scale of 1 to 7 indicates the opinion of taxpayers on the ethics of evading tax resembles to tax evasion is somewhat ethical with different justification that are incorporated in the statements. In fact, as the table shows, some statements mean scores are higher than others, which indicate that some arguments to support tax evasion ethics of the taxpayers are stronger than others. Likewise, Mc Gee [26] compare opinion of two different state, Utah and Florida using same survey and found that some arguments are stronger than others. Furthermore, he also able to identified the relative strength of various arguments.

Table 2. Mean score of the respondents' perception about tax evasion

\begin{tabular}{|c|c|c|}
\hline S\# & Statements & Mean \\
\hline 1 & Tax evasion is ethical if tax rates are too high & 3.5926 \\
\hline 2 & $\begin{array}{l}\text { Tax evasion is ethical even if tax rates are not } \\
\text { too high because the government is not entitled } \\
\text { to take as much as it is taking from me }\end{array}$ & 3.6607 \\
\hline 3 & Tax evasion is ethical if the tax system is unfair & 3.2857 \\
\hline 4 & $\begin{array}{l}\text { Tax evasion is ethical if a large portion of the } \\
\text { money collected is wasted }\end{array}$ & 3.5179 \\
\hline 5 & $\begin{array}{l}\text { Tax evasion is ethical even if most of the } \\
\text { money collected is spent wisely }\end{array}$ & 4.5536 \\
\hline 6 & $\begin{array}{l}\text { Tax evasion is ethical if a large portion of the } \\
\text { money collected is spent on projects that I } \\
\text { morally disapprove of }\end{array}$ & 4.1250 \\
\hline 7 & $\begin{array}{l}\text { Tax evasion is ethical even if a large portion of } \\
\text { the money collected is spent on worthy } \\
\text { projects }\end{array}$ & 4.5357 \\
\hline 8 & $\begin{array}{c}\text { Tax evasion is ethical if a large portion of the } \\
\text { money collected is spent on projects that do not } \\
\text { benefit me }\end{array}$ & 4.2679 \\
\hline 9 & $\begin{array}{c}\text { Tax evasion is ethical even if a large portion of } \\
\text { the money collected is spent on projects that do } \\
\text { benefit me }\end{array}$ & 4.4107 \\
\hline 10 & Tax evasion is ethical if everyone is doing it & 4.1818 \\
\hline 11 & $\begin{array}{l}\text { Tax evasion is ethical if a significant portion of } \\
\text { the money collected winds up in the pockets of } \\
\text { corrupt politicians or their families and friends }\end{array}$ & 2.9818 \\
\hline 12 & $\begin{array}{l}\text { Tax evasion is ethical if the probability of } \\
\text { getting caught is low }\end{array}$ & 4.2222 \\
\hline 13 & $\begin{array}{l}\text { Tax evasion is ethical if some of the proceeds } \\
\text { go to support a war that I consider to be unjust }\end{array}$ & 3.5357 \\
\hline 14 & Tax evasion is ethical if I can't afford to pay & 3.4815 \\
\hline 15 & $\begin{array}{l}\text { Tax evasion is ethical even if it means that if I } \\
\text { pay less, others will have to pay more }\end{array}$ & 4.3750 \\
\hline 16 & $\begin{array}{l}\text { Tax evasion would be ethical if I were a } \\
\text { foreigner/ am not from Dessie }\end{array}$ & 4.2143 \\
\hline 17 & $\begin{array}{l}\text { Tax evasion is ethical if the government } \\
\text { discriminates against me because of my } \\
\text { religion }\end{array}$ & 3.7222 \\
\hline 18 & $\begin{array}{l}\text { Tax evasion is ethical if the government } \\
\text { imprisons people for their political } \\
\text { opinions/Religion affiliation }\end{array}$ & 3.4643 \\
\hline & Mean all of the statements & 3.8960 \\
\hline
\end{tabular}

1 = strongly agree, 2 = agree, 3 = fairly agree, 4 = indifferent, $5=$ fairly disagree, $6=$ disagree, $7=$ strongly disagree

Source: The survey result, 2015 


\subsection{The Ethics of Tax Evasion in Different Demographics Characteristics of Respondents}

\subsubsection{The Ethics of Tax Evasion in different Gender of the Respondents}

Men and female self-employed taxpayers may have different perception about tax evasion. The below survey result discussed this differences.

Table 3. Mean score difference of the respondents' perception about tax evasion in different gender

\begin{tabular}{|c|c|c|c|c|c|c|c|c|}
\hline \multirow[t]{2}{*}{ S\# } & & \multicolumn{2}{|c|}{ Male } & \multicolumn{2}{|c|}{ Female } & \multirow[b]{2}{*}{$\begin{array}{l}\text { Mean } \\
\text { Dif. }\end{array}$} & \multirow[b]{2}{*}{ Sig } & \multirow[b]{2}{*}{$\begin{array}{l}\text { Significance } \\
\text { diff? }\end{array}$} \\
\hline & Statements & Mean & $\begin{array}{c}\text { Std. } \\
\text { Deviation }\end{array}$ & Mean & $\begin{array}{c}\text { Std. } \\
\text { Deviation }\end{array}$ & & & \\
\hline 1 & Tax evasion is ethical if tax rates are too high & 3.4595 & 2.47260 & 3.8125 & 2.46795 & -.35304 & .243 & No \\
\hline 2 & $\begin{array}{l}\text { Tax evasion is ethical even if tax rates are not } \\
\text { too high because the government is not } \\
\text { entitled to take as much as it is taking from me }\end{array}$ & 3.3947 & 2.30540 & 4.1765 & 2.36899 & -.78173 & .005 & Yes \\
\hline 3 & $\begin{array}{c}\text { Tax evasion is ethical if the tax system is } \\
\text { unfair }\end{array}$ & 3.0526 & 2.24037 & 3.7059 & 2.45590 & -.65325 & .023 & Yes \\
\hline 4 & $\begin{array}{l}\text { Tax evasion is ethical if a large portion of the } \\
\text { money collected is wasted }\end{array}$ & 3.1316 & 2.24300 & 4.2353 & 2.40122 & -1.10372 & .000 & Yes \\
\hline 5 & $\begin{array}{l}\text { Tax evasion is ethical even if most of the } \\
\text { money collected is spent wisely }\end{array}$ & 4.4474 & 2.55716 & 4.7059 & 2.03235 & -.25851 & .327 & No \\
\hline 6 & $\begin{array}{l}\text { Tax evasion is ethical if a large portion of the } \\
\text { money collected is spent on projects that I } \\
\text { morally disapprove of }\end{array}$ & 4.0789 & 2.44821 & 4.1765 & 2.13139 & -.09752 & .714 & No \\
\hline 7 & $\begin{array}{c}\text { Tax evasion is ethical even if a large portion of } \\
\text { the money collected is spent on worthy } \\
\text { projects }\end{array}$ & 4.4211 & 2.36306 & 4.7647 & 2.05458 & -.34365 & .182 & No \\
\hline 8 & $\begin{array}{l}\text { Tax evasion is ethical if a large portion of the } \\
\text { money collected is spent on projects that do } \\
\text { not benefit me }\end{array}$ & 4.0263 & 2.23493 & 4.7059 & 1.97303 & -.67957 & .006 & Yes \\
\hline 9 & $\begin{array}{l}\text { Tax evasion is ethical even if a large portion of } \\
\text { the money collected is spent on projects that } \\
\text { do benefit me }\end{array}$ & 4.3684 & 2.40507 & 4.4706 & 2.34080 & -.10217 & .719 & No \\
\hline 10 & Tax evasion is ethical if everyone is doing it & 4.0000 & 2.66152 & 4.5625 & 2.30246 & -.56250 & .057 & Yes \\
\hline 11 & $\begin{array}{l}\text { Tax evasion is ethical if a significant portion } \\
\text { of the money collected winds up in the pockets } \\
\text { of corrupt politicians or their families and } \\
\text { friends }\end{array}$ & 2.6486 & 2.07397 & 3.7647 & 2.27416 & -1.11606 & .000 & Yes \\
\hline 12 & $\begin{array}{l}\text { Tax evasion is ethical if the probability of } \\
\text { getting caught is low }\end{array}$ & 4.0270 & 2.56838 & 4.6471 & 1.94807 & -.62003 & .017 & Yes \\
\hline 13 & $\begin{array}{l}\text { Tax evasion is ethical if some of the proceeds } \\
\text { go to support a war that I consider to be unjust }\end{array}$ & 3.3947 & 2.21178 & 3.8235 & 2.24010 & -.42879 & .106 & No \\
\hline 14 & Tax evasion is ethical if I can't afford to pay & 3.4211 & 2.32926 & 3.6000 & 2.10297 & -.17895 & .527 & No \\
\hline 15 & $\begin{array}{l}\text { Tax evasion is ethical even if it means that if I } \\
\text { pay less, others will have to pay more }\end{array}$ & 4.4737 & 2.48417 & 4.0588 & 2.44878 & .41486 & .160 & No \\
\hline 16 & $\begin{array}{l}\text { Tax evasion would be ethical if I were a } \\
\text { foreigner/ am not from Dessie }\end{array}$ & 4.5526 & 2.59818 & 3.4706 & 2.46442 & 1.08204 & .000 & Yes \\
\hline 17 & $\begin{array}{c}\text { Tax evasion is ethical if the government } \\
\text { discriminates against me because of my } \\
\text { religion }\end{array}$ & 3.6111 & 2.60173 & 3.9412 & 2.52050 & -.33007 & .287 & No \\
\hline 18 & $\begin{array}{l}\text { Tax evasion is ethical if the government } \\
\text { imprisons people for their political opinions }\end{array}$ & 3.1842 & 2.53805 & 4.0588 & 2.54396 & -.87461 & .004 & Yes \\
\hline & Mean of total arguments/ statements & 3.7607 & & 4.1489 & & & .006 & Yes \\
\hline
\end{tabular}

Source: survey result, 2015 
Table 3 indicated that overall Mean ranking and comparison of acceptability of tax evasion across gender shows that females (mean $=4.1489$ ) were significantly more opposed to tax evasion than males (mean $=3.7607, \mathrm{p}=0.006$ ). The result is consistent with prior studies that females are more ethical than males which means that females believe more that tax evasion is unethical [27-30]

However while we see the mean comparison tests of each argument separately, in some situation male and female have no significant difference and in some other they do have significance difference. Hence, the above table depicts that female were significantly more opposed to tax evasion in 8 of 18 arguments. For the other 8 arguments again, female were more opposed to tax evasion, but the differences in mean scores were not significant at the 5 percent significant level. However, only in 1 statement of 18 statements females were significantly less opposed to tax evasion and in 1 argument of 18 female were less opposed to tax evasion, but the differences in mean scores were not significant at the 5 percent significant level. The findings in this study confirm the conclusion that females were more opposed to tax evasion. Mc Gee and Djatej [31] finding supports this study result that Females were more opposed to tax evasion than male.

The table below summarizes significance of differences in female and men opinions.

Table 4. Significance of Differences in female and Men Opinions

\begin{tabular}{|l|c|}
\hline & Arguments/Statement \# \\
\hline $\begin{array}{l}\text { Females were significantly more opposed } \\
\text { to tax evasion }\end{array}$ & $2,3,4,8,10,11,12,18$ \\
\hline $\begin{array}{l}\text { Females were more opposed to tax } \\
\text { evasion, but not significantly }\end{array}$ & $1,5,6,7,9,13,14,17$ \\
\hline $\begin{array}{l}\text { Male were more opposed to tax evasion, } \\
\text { but not significantly }\end{array}$ & 15 \\
\hline $\begin{array}{l}\text { Male were significantly more opposed to } \\
\text { tax evasion }\end{array}$ & 16 \\
\hline
\end{tabular}

Table 4 summarizes the findings on the mean difference between men and female taxpayers. Accordingly, the females were significantly more opposed to tax evasion in 8 cases whereas men significantly more opposed to tax evasion in 1 argument. Likewise, the females were more opposed to tax evasion in 8 cases whereas men more opposed to tax evasion in 1 argument, though there is no statistical differences. This implies that in regard with tax evasion females are more ethical than males.

Table 5 below summarizes arguments where female are significantly opposed to tax vision
Table 5. Arguments where female were significantly more Opposed to Tax Evasion

\begin{tabular}{|l|c|}
\hline \multicolumn{1}{|c|}{ Statements } & S\# \\
\hline $\begin{array}{l}\text { Tax evasion is ethical even if tax rates are not too high } \\
\text { because the government is not entitled to take as much } \\
\text { as it is taking from me }\end{array}$ & 2 \\
\hline Tax evasion is ethical if the tax system is unfair & 3 \\
\hline $\begin{array}{l}\text { Tax evasion is ethical if a large portion of the money } \\
\text { collected is wasted }\end{array}$ & 8 \\
\hline $\begin{array}{l}\text { Tax evasion is ethical if a large portion of the money } \\
\text { collected is spent on projects that do not benefit me }\end{array}$ & 10 \\
\hline Tax evasion is ethical if everyone is doing it & 11 \\
\hline $\begin{array}{l}\text { Tax evasion is ethical if a significant portion of the } \\
\text { money collected winds up in the pockets of corrupt } \\
\text { politicians or their families and friends }\end{array}$ & 12 \\
\hline $\begin{array}{l}\text { Tax evasion is ethical if the probability of getting } \\
\text { caught is low }\end{array}$ & 18 \\
\hline $\begin{array}{l}\text { Tax evasion is ethical if the government imprisons } \\
\text { people for their political opinions }\end{array}$ & \\
\hline
\end{tabular}

The above table lists the cases where the females were significantly more opposed to tax evasion.

Whereas only on the case of "Tax evasion is ethical even if it means that if I pay less, others will have to pay more" men were significantly more opposed to tax evasion than were female. It was thought that female scores would be higher than male scores $[26,32$,]. The present study reaches the same result with those literatures.

\subsubsection{The Ethics of Tax Evasion in different Educational status of the Respondents}

Self-employed taxpayers in different academic status may have different perception about tax evasion. The below survey result depicts this differences.

Table 6 indicated overall Mean ranking and comparison of acceptability of tax evasion across different academic status. It shows that respondents with academic status above diploma ( mean $=4.2629$ ) were significantly more opposed to tax evasion than respondents with academic status of below diploma (mean $=3.5600, \mathrm{p}=.000$ ). While we see other countries studies, according to McGee and Yuhua [33], they found that, however, the difference in education level is insignificant. But, Harun, Abu Bakar, and Tahir [20] reviewed their findings contradict to the studies in Korea, Japan and China (Mainland) as well as the current study, that higher education levels are opposed to tax evasion. 
Table 6. Mean score difference of the respondents' perception about tax evasion in different educational status

\begin{tabular}{|c|c|c|c|c|c|c|c|c|}
\hline \multirow[b]{2}{*}{ \#S } & \multirow[b]{2}{*}{ Arguments/ statements } & \multicolumn{2}{|c|}{ Below diploma } & \multicolumn{2}{|c|}{ Diploma and above } & \multirow[b]{2}{*}{$\begin{array}{c}\text { Mean } \\
\text { difference }\end{array}$} & \multirow[b]{2}{*}{ Sig } & \multirow[b]{2}{*}{$\begin{array}{c}\text { Significance } \\
\text { diff? }\end{array}$} \\
\hline & & Mean & \begin{tabular}{|c|} 
Std. \\
Deviation
\end{tabular} & Mean & $\begin{array}{c}\text { Std. } \\
\text { Deviation }\end{array}$ & & & \\
\hline 1 & Tax evasion is ethical if tax rates are too high & 3.3793 & 2.39093 & 3.7917 & 2.55807 & -.41236 & .142 & NO \\
\hline 2 & $\begin{array}{l}\text { Tax evasion is ethical even if tax rates are not too high because } \\
\text { the government is not entitled to take as much as it is taking from } \\
\text { me }\end{array}$ & 3.5000 & 2.45291 & 3.8000 & 2.21647 & -.30000 & .249 & NO \\
\hline 3 & Tax evasion is ethical if the tax system is unfair & 2.8667 & 2.19293 & 3.7200 & 2.40000 & -.85333 & .001 & YES \\
\hline 4 & $\begin{array}{c}\text { Tax evasion is ethical if a large portion of the money collected is } \\
\text { wasted }\end{array}$ & 3.1667 & 2.24355 & 3.8400 & 2.41938 & -.67333 & .009 & YES \\
\hline 5 & \begin{tabular}{|c|}
$\begin{array}{c}\text { Tax evasion is ethical even if most of the money collected is } \\
\text { spent wisely }\end{array}$ \\
\end{tabular} & 4.2000 & 2.33602 & 4.9200 & 2.43994 & -.72000 & .007 & YES \\
\hline 6 & $\begin{array}{c}\text { Tax evasion is ethical if a large portion of the money collected is } \\
\text { spent on projects that I morally disapprove of }\end{array}$ & 3.5667 & 2.31125 & 4.7600 & 2.23961 & -1.19333 & .000 & YES \\
\hline 7 & $\begin{array}{c}\text { Tax evasion is ethical even if a large portion of the money } \\
\text { collected is spent on worthy projects }\end{array}$ & 3.9000 & 2.12487 & 5.2800 & 2.22590 & -1.38000 & .000 & YES \\
\hline 8 & $\begin{array}{l}\text { Tax evasion is ethical if a large portion of the money collected is } \\
\text { spent on projects that do not benefit me }\end{array}$ & 3.8000 & 2.20310 & 4.7600 & 2.03222 & -.96000 & .000 & YES \\
\hline 9 & $\begin{array}{c}\text { Tax evasion is ethical even if a large portion of the money } \\
\text { collected is spent on projects that do benefit me }\end{array}$ & 4.0667 & 2.44172 & 4.8000 & 2.25252 & -.73333 & .005 & YES \\
\hline 10 & Tax evasion is ethical if everyone is doing it & 3.7333 & 2.60125 & 4.7083 & 2.43194 & -.97500 & .001 & YES \\
\hline 11 & $\begin{array}{c}\text { Tax evasion is ethical if a significant portion of the money } \\
\text { collected winds up in the pockets of corrupt politicians or their } \\
\text { families and friends }\end{array}$ & 2.7667 & 2.09842 & 3.2917 & 2.28976 & -.52500 & .034 & YES \\
\hline 12 & Tax evasion is ethical if the probability of getting caught is low & 3.9333 & 2.45541 & 4.5833 & 2.29776 & -.65000 & .015 & YES \\
\hline 13 & $\begin{array}{c}\text { Tax evasion is ethical if some of the proceeds go to support a war } \\
\text { that I consider to be unjust }\end{array}$ & 3.2667 & 2.32931 & 3.8400 & 2.05978 & -.57333 & .018 & YES \\
\hline 14 & Tax evasion is ethical if I can't afford to pay & 3.1034 & 2.31624 & 3.9167 & 2.12708 & -.81322 & .001 & YES \\
\hline 15 & $\begin{array}{c}\text { Tax evasion is ethical even if it means that if I pay less, others } \\
\text { will have to pay more }\end{array}$ & 4.1333 & 2.61153 & 4.6000 & 2.28799 & -.46667 & .085 & $\mathrm{NO}$ \\
\hline 16 & $\begin{array}{c}\text { Tax evasion would be ethical if I were a foreigner/ am not from } \\
\text { Dessie }\end{array}$ & 4.0667 & 2.60125 & 4.4000 & 2.60098 & -.33333 & .247 & NO \\
\hline 17 & $\begin{array}{c}\text { Tax evasion is ethical if the government discriminates against } \\
\text { me because of my religion }\end{array}$ & 3.3571 & 2.56014 & 4.1200 & 2.54337 & -.76286 & .008 & YES \\
\hline 18 & $\begin{array}{l}\text { Tax evasion is ethical if the government imprisons people for } \\
\text { their political opinions/Religion affiliation }\end{array}$ & 3.3333 & 2.61922 & 3.6000 & 2.50637 & -.26667 & .348 & NO \\
\hline & Mean of total arguments/ statements & 3.5633 & & 4.2629 & & -.69954 & .000 & YES \\
\hline
\end{tabular}

Source: survey result, 2015

Likewise, while we see the mean comparison tests of each argument separately, in fact, in all of the argument/statements educated respondents oppose tax evasion than uneducated. However, statistically, the above table depicts that educated were significantly more opposed to tax evasion in 13 of 18 arguments. For the other 5 arguments again, educated respondents were more opposed to tax evasion, but the differences in mean scores were not significant at the 5 percent significant level. Overall, it can be concluded that educated taxpayers are more ethical than uneducated in evading tax, given that tax evasion is unethical. The table below summarizes the arguments to which educated respondents were significantly more opposed to tax evasion than uneducated.

Table 7. Arguments where educated respondents were significantly more opposed to Tax Evasion than uneducated

\begin{tabular}{|c|c|}
\hline Arguments/ statements & AS \\
\hline Tax evasion is ethical if a large portion of the money collected is wasted & 3 \\
\hline Tax evasion is ethical even if most of the money collected is spent wisely & 4 \\
\hline Tax evasion is ethical if a large portion of the money collected is spent on projects that I morally disapprove of & 5 \\
\hline Tax evasion is ethical even if a large portion of the money collected is spent on worthy projects & 6 \\
\hline Tax evasion is ethical if a large portion of the money collected is spent on projects that do not benefit me & 7 \\
\hline Tax evasion is ethical even if a large portion of the money collected is spent on projects that do benefit me & 9 \\
\hline Tax evasion is ethical if everyone is doing it & 10 \\
\hline Tax evasion is ethical if the probability of getting caught is low & 11 \\
\hline Tax evasion is ethical if a significant portion of the money collected winds up in the pockets of corrupt politicians or their families and & \\
\hline Tax evasion is ethical if some of the proceeds go to support a war that I consider to be unjust & 12 \\
\hline Tax evasion is ethical if the government discriminates against me because of my religion & 13 \\
\hline
\end{tabular}


In all the arguments listed table 13 educated self-employed taxpayers significantly oppose tax evasion than uneducated self-employed taxpayers. They are more ethical on to evade tax on those situation of taxpaying than less educated I.e. educated taxpayers believe that evading tax in those situation unethical.

\subsection{Taxpayers' Most Widespread Ethical Justification and Oppositions for Tax Evasion}

\subsubsection{Ranking of Ethical Arguments for Tax Evasion}

Taxpayers raise some issues more in emphasis than others to justify their tax evasion behavior. The table below depicts the ranked mean score of respondents' opinion of the 18 statements/arguments forwarded to describe their ethics of tax evasion.

In the table 8, the various arguments that respondents gave to justify tax evasion in Dessie town are reported. The argument against the 18 Statements are ranked from strongest to weakest for the support of evading tax. The range is 2.9818 mean score to 4.5536 mean score, which indicates that there is a various support among respondents for the position that tax evasion is ethical in some circumstances.

The table ranks the scores for the 18 statements from the point of view that tax evasion is ethical in one spectrum and tax evasion is unethical in the other end of the spectrum. Accordingly, the strongest agreement that tax evasion is ethical is the case where a significant portion of the money collected winds up in the pockets of corrupt politicians or their families and friends. This implies that taxpayers do not have an ethical problem with evading taxes because their governments are corrupt and they feel that they have no ethical duty to pay taxes to a corrupt government. The other agreement for point of view that tax evasion is ethical appears in the second rank when the tax system is unfair. Likewise, McGee and Bernal (2006) surveyed that tax evasion might be ethical within the framework of reasonable grounds. Strong reasons to justify tax evasion that accepts when government is in corruption or tax system is unfair

Table 8. mean score ranks of ethical arguments for tax evasion

\begin{tabular}{|c|c|}
\hline Arguments/ statements & Mean \\
\hline $\begin{array}{l}\text { Tax evasion is ethical if a significant portion of the money collected winds up in the pockets of corrupt politicians } \\
\text { or their families and friends }\end{array}$ & 2.9818 \\
\hline Tax evasion is ethical if the tax system is unfair & 3.2857 \\
\hline Tax evasion is ethical if the government imprisons people for their political opinions/Religion affiliation & 3.4643 \\
\hline Tax evasion is ethical if I can't afford to pay & 3.4815 \\
\hline Tax evasion is ethical if a large portion of the money collected is wasted & 3.5179 \\
\hline Tax evasion is ethical if some of the proceeds go to support a war that I consider to be unjust & 3.5357 \\
\hline Tax evasion is ethical if tax rates are too high & 3.5926 \\
\hline $\begin{array}{l}\text { Tax evasion is ethical even if tax rates are not too high because the government is not entitled to take as much as } \\
\text { it is taking from me }\end{array}$ & 3.6607 \\
\hline Tax evasion is ethical if the government discriminates against me because of my religion & 3.7222 \\
\hline Tax evasion is ethical if a large portion of the money collected is spent on projects that I morally disapprove of & 4.1250 \\
\hline Tax evasion is ethical if everyone is doing it & 4.1818 \\
\hline Tax evasion would be ethical if I were a foreigner/ am not from Dessie & 4.2143 \\
\hline Tax evasion is ethical if the probability of getting caught is low & 4.2222 \\
\hline Tax evasion is ethical if a large portion of the money collected is spent on projects that do not benefit me & 4.2679 \\
\hline Tax evasion is ethical even if it means that if I pay less, others will have to pay more & 4.3750 \\
\hline Tax evasion is ethical even if a large portion of the money collected is spent on projects that do benefit me & 4.4107 \\
\hline Tax evasion is ethical even if a large portion of the money collected is spent on worthy projects & 4.5357 \\
\hline Tax evasion is ethical even if most of the money collected is spent wisely & 4.5536 \\
\hline Valid N (listwise) & \\
\hline
\end{tabular}

The likert scale measurement ranges: score ranges: $1=$ strongly agree. $. .7=$ strongly disagree

Source: survey result, 2015 
As to the respondents' response, the third ranked agreement to justify tax evasion behaviour of the taxpayers is when the government imprisons people for their political opinions/Religion affiliations. Relatively with the same magnitude the third ranked view the fourth ranked opinion is to justify tax evasion is when taxpayers can't afford to pay. In the fifth rank, the respondents indicate to the fact of wasting a large proportion of tax collected. The sixth ranked is taking the tax proceed to support a war that taxpayers consider unjust. The seventh rank indicated the high tax rate. In the eighth rank, the respondents indicate that tax evasion is ethical even if tax rates are not too high because the government is not entitled to take as much as it is taking from taxpayers. The ninth rank comes with a view related to the discrimination practices of the government in terms of taxpayers' religion. The tenth mean score rank indicates the view of spending money on projects that are morally disapproved of. Whereas, the eleventh rank indicates to whether the practice of tax evasion is every ones act. In the twelfth rank respondents mean score reflected that tax evasion would be ethical if taxpayers were a foreigner/ not from Dessie. Likewise, the thirteenth rank comes with a view of low probability of getting caught by the tax authority. The fourteenth rank implies to the spending of the tax collected on support of projects that do not benefit taxpayers. In the fifteenth, what is indicated is that that tax evasion is ethical regardless of the lesser tax to be paid in comparison with other. The sixteenth rank is the view of spending a large portion of the money collected on projects that benefit taxpayers. As well, the seventeenth rank is the view of spending a large portion of the money on worthy projects. The last rank, eighteenth, is the view of spending the money wisely.

\subsubsection{Taxpayers' Most Widespread Ethical Justification for Tax Evasion}

In the above mean score rank table, the top six (6) ranking arguments in justifying tax evasion and which have the mean score below the average of the scale (agreement level) are; government corruption, unfair tax system, government discrimination against political affiliation, tax affordability, when a large portion of the money collected is wasted, and high tax rate. This shows that the responsiveness of government in terms of accountability, human right treatment and optimal tax rate play a significant role in the payment of taxes by this group of taxpayers. Likewise, in other studies as reviewed by McGee, Aljaaidi \& Musaibah [13], respondent justify tax evasion by giving stronger support in some circumstance than others. In these studies, respondents consider tax evasion as an ethical practice if the tax system is unfair, the government is corrupt, wasteful, or if the government engages in human rights abuses.

\subsubsection{Taxpayers' Most Widespread Ethical Oppositions for Tax Evasion}

In contrary to justification for tax evasion, there are also situations that taxpayers avoid evading tax. The most opposition to tax evasion occurred in cases when most of the money collected is spent wisely, if a large portion of the money collected is spent on worthy projects, when a large portion of the money collected is spent on projects that do benefit me, when a large portion of the money collected is spent on projects that do not benefit me and if it means that if I pay less, others will have to pay more. Likewise some other studies that have been conducted using a similar survey instrument in other country as McGee, Aljaaidi \& Musaibah [13] reviewed in different researches that respondents are opposed to tax evasion when tax rates are not high, or when the money collected are spent wisely and on worthy project

The other findings of this study from the above table mean score rank is that while we notice statements which have higher mean score in this study (suggesting higher opposition to tax evasion), they explicitly espouses a selfish motive. As indicated in the above table, all of the statements with mean scores of 4.1 and higher fall into this category. This finding is, in fact, consistent with other studies [25, 26], that the statements with the highest scores (suggesting higher opposition to tax evasion) are the ones that espouse a selfish motive. This study result merely confirms that statements that espouse selfish motives were found to be less justifiable in the minds of our self employed taxpayers.

However, while we see the order of argument level of each statement, the studies reported that different countries have different perception regarding ethics on tax evasion. For example, in China (Mainland) and Mali, the stronger argument is item number 4 (Tax evasion is ethical if a large portion of the money collected is wasted) where the mean score are 3.04 and 3.61 respectively. However, in the current study the primary stronger argument is statement number 11 which states that tax evasion is ethical if a significant portion of the money collected winds up in the pockets of corrupt politicians or their families and friends (mean score 2.98). In fact, as reviewed by Harun etal [20] in different researches this study result is similar with other countries like Taiwan, USA, Hong Kong and US. That difference may be the perception of the society for the situation like corruption.

\subsubsection{Ranks of Ethical Arguments for Tax Evasion in Different Gender}

Female and male self-employed taxpayers rank the different tax ethics arguments differently which means that male and female respondents have different opposition as well as support to tax evasion that is indicated in the table below. Table 15, summarizes the ranking of ethical arguments for both genders.

The following table reviews the relative ranking of reasons for justifying tax evasion. 
Table 9. Mean score of the respondents perception about tax evasion in different gender

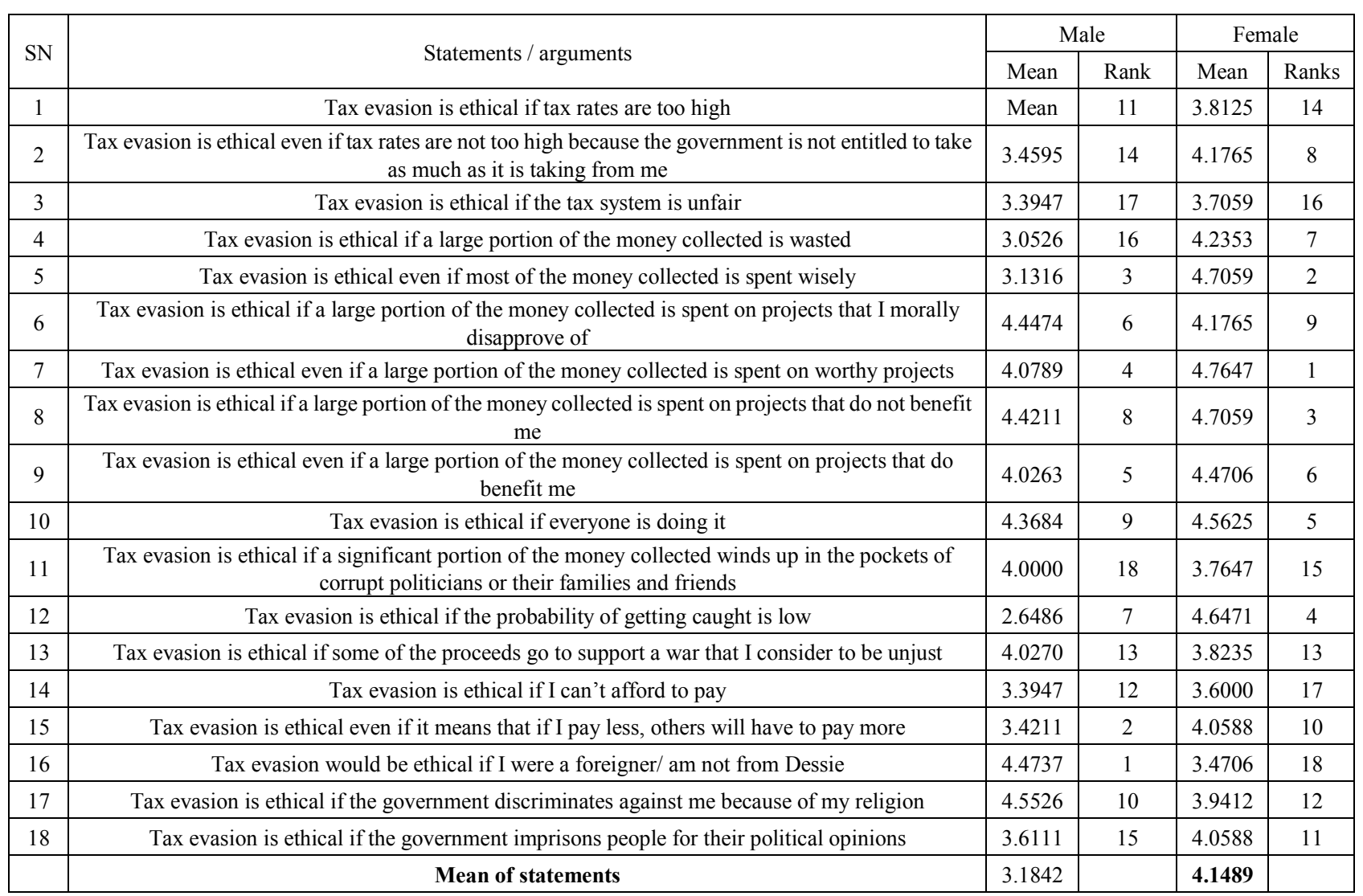

$(1=$ most opposed; $18=$ least opposed $)$, and the likert scale measurement ranges: score ranges: $1=$ strongly agree... $7=$ strongly disagree)

Source: Survey result, 2015

Table 9 ranks the various reasons given to justify tax evasion as well as opposition by different gender group of the respondents, from most opposed to tax evasion to least opposed. The female rankings are somewhat different from the male rankings. However, in only one statement/ argument was very similar which is "Tax evasion is ethical if some of the proceeds go to support a war that I consider being unjust" and ranked at $13^{\text {th }}$ in both gender groups. Again, in statements 3, 5, and 9 they are almost similar. But, in others statements the female rankings and men rankings are somewhat different.

For female respondents, sequentially from the first to fifth, the most opposition to tax evasion tended to be in arguments where a large portion of the money collected is spent on worthy projects (mean score of 4.7647), if most of the money collected is spent wisely (mean score of 4.7059), where a large portion of the money collected is spent on projects that do not benefit me (mean score of 4.7059), when the probability of getting caught is low (mean score of 4.6471), and where everyone is doing it (mean score of 4.5625)

Whereas, for male respondents, the most opposition to tax evasion tended to be in cases where a taxpayer were a foreigner (mean score of 4.5526), if it means that if I pay less, others will have to pay more(mean score of 4.4737), when most of the money collected is spent wisely (mean score of 4.4474), where if a large portion of the money collected is spent on worthy projects(mean score of 4.4211), and if a large portion of the money collected is spent on projects that do benefit me(mean score of 4.3684).

In contrast, for female, the least opposition to tax evasion occurred in cases where taxpayer were a foreigner (mean score of 3.4706), if I can't afford to pay (mean score of 3.6000), when the tax system is unfair (mean score of 3.7059), where a significant portion of the money collected winds up in the pockets of corrupt politicians or their families and friends (mean score of 3.7647), and when tax rates are too high (mean score of 3.8125).

Likewise, for men, the least opposition to tax evasion occurred in cases where a significant portion of the money collected winds up in the pockets of corrupt politicians or their families and friends (mean score of 2.6486), if the tax system is unfair (mean score of 3.0526), when a large portion of the money collected is wasted (mean score of 3.1316), where the government imprisons people for their political opinions (mean score of 3.1842), and where even if tax rates are not too high because the government is not entitled to take as much as it is taking from me (mean score of 3.3947).

The one notable exception was in the case where taxpayers were foreigners. In that case, the female ranking was $18^{\text {th }}$, whereas the male ranking was $1^{\text {st }}$, meaning that for female evading tax is ethical for foreigners. In reverse, males are strongly opposing evading tax for foreigners thinking 
they are outsiders.

The common, for both male and female, most opposition to tax evasion tended to be in cases where a large portion of the money collected is spent on worthy projects, whereas the least opposition to tax evasion occurred in cases where a significant portion of the money collected winds up in the pockets of corrupt politicians or their families and friends and if the tax system is unfair.

\subsubsection{Ranks of Ethical Arguments for Tax Evasion in Different Academic Status of Respondents}

Table 10 ranks the various reasons given to justify tax evasion as well as oppositions over different academic status of the respondents, from most opposed to least opposed. Accordingly, the most five situation that less educated taxpayers oppose evading tax are; evading tax if the money collected is spent wisely (4.2000), if one pays less than others (4.1333), if one evades tax thinking he/she is foreigner/ not from Dessie (4.0667), if a large portion of the money collected is spent on projects that do benefit taxpayers (4.0667) and thinking the probability of getting caught is low (3.9333).

In contrast, for less educated respondents, the strongest arguments to evade tax occurred in cases where a significant portion of the money collected winds up in the pockets of corrupt politicians or their families and friends (2.7667), where the tax system is unfair (2.8667), if taxpayers can't afford to pay (3.1034), when a large portion of the money collected is wasted (3.1667), where some of the proceeds go to support a war that taxpayers consider to be unjust (3.2667), and when the government imprisons people for their political opinions/Religion affiliation (3.333).

On the other hand, for educated respondents, the most opposition to tax evasion tended to be in cases where a large portion of the money collected is spent on worthy projects (5.2800), if most of the money collected is spent wisely (4.9200), when a large portion of the money collected is spent on projects that do benefit taxpayers (4.800), where a large portion of the money collected is spent on projects that do not benefit me (4.7600) and when a large portion of the money collected is spent on projects that taxpayers morally disapprove of.

On the opposite, for educated men, the least opposition to tax evasion occurred in cases where a significant portion of the money collected winds up in the pockets of corrupt politicians or their families and friends (3.2917), if the government imprisons people for their political opinions/Religion affiliation (3.6000), when the tax system is unfair (3.7200), where tax rates are too high (3.7917), and if tax rates are not too high because the government is not entitled to take as much as it is taking from me(3.8000).

Table 10. The ranking of ethical arguments over the different academic status of the respondents

\begin{tabular}{|c|c|c|c|c|c|}
\hline \multicolumn{6}{|c|}{ Descriptive Statistics } \\
\hline \multirow[t]{2}{*}{ S\# } & \multirow[t]{2}{*}{ Arguments/statements } & \multicolumn{2}{|c|}{$\begin{array}{l}\text { Diploma and below (less } \\
\text { educated) }\end{array}$} & \multicolumn{2}{|c|}{$\begin{array}{l}\text { Above diploma } \\
\text { (educated ) }\end{array}$} \\
\hline & & Mean & Rank & Mean & Rank \\
\hline 1 & Tax evasion is ethical if tax rates are too high & 3.3793 & 11 & 3.7917 & 15 \\
\hline 2 & $\begin{array}{c}\text { Tax evasion is ethical even if tax rates are not too high because the government is not entitled } \\
\text { to take as much as it is taking from me }\end{array}$ & 3.5000 & 10 & 3.8000 & 14 \\
\hline 3 & \begin{tabular}{|l|l} 
Tax evasion is ethical if the tax system is unfair \\
\end{tabular} & 2.8667 & 17 & 3.7200 & 16 \\
\hline 4 & Tax evasion is ethical if a large portion of the money collected is wasted & 3.1667 & 15 & 3.8400 & 13 \\
\hline 5 & Tax evasion is ethical even if most of the money collected is spent wisely & 4.2000 & 1 & 4.9200 & 2 \\
\hline 6 & $\begin{array}{l}\text { Tax evasion is ethical if a large portion of the money collected is spent on projects that I } \\
\text { morally disapprove of }\end{array}$ & 3.5667 & 9 & 4.7600 & 5 \\
\hline 7 & $\begin{array}{l}\text { Tax evasion is ethical even if a large portion of the money collected is spent on worthy } \\
\text { projects }\end{array}$ & 3.9000 & 6 & 5.2800 & 1 \\
\hline 8 & $\begin{array}{c}\text { Tax evasion is ethical if a large portion of the money collected is spent on projects that do not } \\
\text { benefit me }\end{array}$ & 3.8000 & 7 & 4.7600 & 4 \\
\hline 9 & $\begin{array}{l}\text { Tax evasion is ethical even if a large portion of the money collected is spent on projects that } \\
\text { do benefit me }\end{array}$ & 4.0667 & 4 & 4.8000 & 3 \\
\hline 10 & \begin{tabular}{|l|} 
Tax evasion is ethical if everyone is doing it \\
\end{tabular} & 3.7333 & 8 & 4.7083 & 6 \\
\hline 11 & $\begin{array}{c}\text { Tax evasion is ethical if a significant portion of the money collected winds up in the pockets } \\
\text { of corrupt politicians or their families and friends }\end{array}$ & 2.7667 & 18 & 3.2917 & 18 \\
\hline 12 & Tax evasion is ethical if the probability of getting caught is low & 3.9333 & 5 & 4.5833 & 8 \\
\hline 13 & Tax evasion is ethical if some of the proceeds go to support a war that I consider to be unjust & 3.2667 & 14 & 3.8400 & 12 \\
\hline 14 & \begin{tabular}{|l|l|} 
Tax evasion is ethical if I can't afford to pay \\
\end{tabular} & 3.1034 & 16 & 3.9167 & 11 \\
\hline 15 & Tax evasion is ethical even if it means that if I pay less, others will have to pay more & 4.1333 & 2 & 4.6000 & 7 \\
\hline 16 & Tax evasion would be ethical if I were a foreigner/ am not from Dessie & 4.0667 & 3 & 4.4000 & 9 \\
\hline 17 & Tax evasion is ethical if the government discriminates against me because of my religion & 3.3571 & 12 & 4.1200 & 10 \\
\hline 18 & $\begin{array}{l}\text { Tax evasion is ethical if the government imprisons people for their political } \\
\text { opinions/Religion affiliation }\end{array}$ & 3.3333 & 13 & 3.6000 & 17 \\
\hline
\end{tabular}

( 1 = most opposed; $18=$ least opposed $)$, and the likert scale measurement ranges: score ranges: $1=$ strongly agree $\ldots 7=$ strongly disagree $)$ 
Overall, for both less educated and educated respondents, the least opposition to tax evasion tended to be in cases where a significant portion of the money collected winds up in the pockets of corrupt politicians or their families and friends, whereas the most opposition to tax evasion occurred in cases where most of the money collected is spent wisely.

\subsection{The Views on the Ethics of Tax Evasion}

Literatures divide the views on the ethics of tax evasion into three category as; tax evasion is always or almost always ethical if the mean score is 2 or less, tax evasion is sometimes ethical if the score is more than 2 but less than 6 , and tax evasion is never or almost never ethical if the score is 6 or higher. Hence, accordingly, the survey result of this study is describe in the below table to determine whether tax evasion is justifiable, sometime justifiable, or never justifiable in the study area.

Table 11 shows that, according to the above category of mean scores of statements of survey to describe the ethics of tax evasion, the means score of all the 18 statements fall into the 'sometimes ethical' category because of the mean scores are more than 2 but less than 6 . It can be seen from the table that by average score all responses fall into the sometimes ethical category because average score of all the statements is 3.8960 and ranges from 2.9818 to 4.5536 (disagree) for each statement responses. Therefore, it can be concluded that the average respondent of the study area does not believe that tax evasion is always or almost always ethical, neither do they believe that tax evasion is never or almost never ethical. Hence, this indicates that tax evasion is sometimes justifiable in this study area. Opinion surveys in other country like Argentina [26, 32,] and a few other countries found that there is widespread support for the position that tax evasion is sometimes ethically justifiable which go in line with current study result. In fact, to be directly comparable one must begin with the premise that tax evasion is unethical, which might not always be the case.

Table 11. the level of justification of the respondent

\begin{tabular}{|c|c|c|}
\hline Statements & Mean & justifiability \\
\hline $\begin{array}{l}\text { Tax evasion is ethical if a significant portion of the money collected winds up in } \\
\text { the pockets of corrupt politicians or their families and friends }\end{array}$ & 2.9818 & sometimes justifiable \\
\hline Tax evasion is ethical if the tax system is unfair & 3.2857 & sometimes justifiable \\
\hline $\begin{array}{l}\text { Tax evasion is ethical if the government imprisons people for their political } \\
\text { opinions/Religion affiliation }\end{array}$ & 3.4643 & sometimes justifiable \\
\hline Tax evasion is ethical if I can't afford to pay & 3.4815 & sometimes justifiable \\
\hline Tax evasion is ethical if a large portion of the money collected is wasted & 3.5179 & sometimes justifiable \\
\hline $\begin{array}{l}\text { Tax evasion is ethical if some of the proceeds go to support a war that I consider } \\
\text { to be unjust }\end{array}$ & 3.5357 & sometimes justifiable \\
\hline Tax evasion is ethical if tax rates are too high & 3.5926 & sometimes justifiable \\
\hline $\begin{array}{l}\text { Tax evasion is ethical even if tax rates are not too high because the government is } \\
\text { not entitled to take as much as it is taking from me }\end{array}$ & 3.6607 & sometimes justifiable \\
\hline $\begin{array}{c}\text { Tax evasion is ethical if the government discriminates against me because of my } \\
\text { religion }\end{array}$ & 3.7222 & sometimes justifiable \\
\hline $\begin{array}{c}\text { Tax evasion is ethical if a large portion of the money collected is spent on projects } \\
\text { that I morally disapprove of }\end{array}$ & 4.1250 & sometimes justifiable \\
\hline Tax evasion is ethical if everyone is doing it & 4.1818 & sometimes justifiable \\
\hline Tax evasion would be ethical if I were a foreigner/ am not from Dessie & 4.2143 & sometimes justifiable \\
\hline Tax evasion is ethical if the probability of getting caught is low & 4.2222 & sometimes justifiable \\
\hline $\begin{array}{c}\text { Tax evasion is ethical if a large portion of the money collected is spent on projects } \\
\text { that do not benefit me }\end{array}$ & 4.2679 & sometimes justifiable \\
\hline $\begin{array}{c}\text { Tax evasion is ethical even if it means that if I pay less, others will have to pay } \\
\text { more }\end{array}$ & 4.3750 & sometimes justifiable \\
\hline $\begin{array}{c}\text { Tax evasion is ethical even if a large portion of the money collected is spent on } \\
\text { projects that do benefit me }\end{array}$ & 4.4107 & sometimes justifiable \\
\hline $\begin{array}{l}\text { Tax evasion is ethical even if a large portion of the money collected is spent on } \\
\text { worthy projects }\end{array}$ & 4.5357 & sometimes justifiable \\
\hline Tax evasion is ethical even if most of the money collected is spent wisely & 4.5536 & sometimes justifiable \\
\hline Mean of all the statement & 3.8960 & sometimes justifiable \\
\hline
\end{tabular}

Mean $<=2$ = always justifiable, mean $>2-<=6=$ sometimes justifiable, mean $>6=$ never justifiable

Source: The survey result, 2015 
However, though the average score indicated that tax evasion is sometimes ethical as a whole, it differs over the different statements in fact. In certain statements tax evasion is never ethical and some other always ethical. That is because, though, comparing average scores tell a lot about perceptions of tax evasion but they don't tell the whole story. For example, a statement can have an average of 4.00 if all the responses were 4 but it can also have an average of 4.00 if half of the respondents selected 7 and the other half selected 1. Hence, one way to approach this "average" problem would be to calculate the percent of total responses that list tax evasion as always or almost always unethical and for the other categories too. Therefore, these calculations are shown in below Table. As describe above, for purposes of analysis the categories are defined as "always or almost always unethical" to be scores of 6 or 7; never or almost never unethical to be scores of 1 or 2; and "sometimes ethical" to be scores of 3,4 or 5 . The percentages in each column represent percentages of each category from the total response.

Table 12 highlighted the extent of support for each of the three positions- tax evasion is always or almost always ethical, tax evasion is sometimes ethical and tax evasion is never or almost never ethical.

The table shows that majority of taxpayers believe that of the total 18 statement, tax evasion is 'never or almost never ethical' on the 9 statements which are S\#5, S\# 6, S\# 7, S\# 8, S\# 9, S\# 10, S\# 12, S\# 15, And S\# 16. This tells us that tax evasion is unacceptable in the view of taxpayers if the money collected is spent wisely, and on worthy projects, if a large portion of the money collected is spent on projects regardless that do benefit them or not. And taxpayers also believe evading tax is unethical even though it is everyone act and probability of getting caught is low. Furthermore, respondents believe that it is not ethical to evade tax even when large portion of the money collected is spent on projects that I morally disapprove of.

In the other side, the other majority of taxpayers believe that from the total 18 statement, tax evasion is 'always or almost always ethical', on the other 9 statements which are S\#1, S\#2, S\# 3, S\# 4, S\# 11, S\# 13, S\# 14, S\# 17, And S\# 18. This implies that, in the view of taxpayers, evading tax is ethical when there is high tax rate, unfair tax system, the money collected wasted, corruption, unjust war, unaffordable tax amount, government discriminate against taxpayers' religion, and when the government discriminates people against their political affiliation.

Seeing the three positions (category), surprisingly, the "sometimes" category had zero proportion adherents out of 18 statements. Therefore, the two dominant positions were "never or almost never" (9 out of 18 statements) and the "always or almost always" category ( 9 out of 18 statements). Hence, it can be concluded that in certain situation it is always ethical for taxpayers to evade tax and in some other situation it is never ethical to evade tax. Below statements under each category are discussed with their rank.

Table 12. Comparison of Responses in percentages for each level of justification of respondents

\begin{tabular}{|c|c|c|c|c|}
\hline S\# & Statements & $\begin{array}{l}\% \text { always or almost } \\
\text { always ethical }(1 \& 2)\end{array}$ & $\begin{array}{l}\text { \% Sometimes } \\
\text { ethical }(3-4-5)\end{array}$ & $\begin{array}{r}\% \text { Never or almost } \\
\text { never ethical }(6 \& 7)\end{array}$ \\
\hline 1 & Tax evasion is ethical if tax rates are too high & $44.4 \%$ & $18.5 \%$ & $37.0 \%$ \\
\hline 2 & $\begin{array}{l}\text { Tax evasion is ethical even if tax rates are not too high because the } \\
\text { government is not entitled to take as much as it is taking from me }\end{array}$ & $41.1 \%$ & $26.8 \%$ & $32.1 \%$ \\
\hline 3 & Tax evasion is ethical if the tax system is unfair & $50.0 \%$ & $23.2 \%$ & $26.8 \%$ \\
\hline 4 & Tax evasion is ethical if a large portion of the money collected is wasted & $44.6 \%$ & $23.2 \%$ & $32.1 \%$ \\
\hline 5 & Tax evasion is ethical even if most of the money collected is spent wisely & $30.4 \%$ & $17.9 \%$ & $\mathbf{5 1 . 8 \%}$ \\
\hline 6 & $\begin{array}{l}\text { Tax evasion is ethical if a large portion of the money collected is spent } \\
\text { on projects that I morally disapprove of }\end{array}$ & $35.7 \%$ & $21.4 \%$ & $42.9 \%$ \\
\hline 7 & $\begin{array}{l}\text { Tax evasion is ethical even if a large portion of the money collected is } \\
\text { spent on worthy projects }\end{array}$ & $28.6 \%$ & $21.4 \%$ & $50.0 \%$ \\
\hline 8 & $\begin{array}{l}\text { Tax evasion is ethical if a large portion of the money collected is spent } \\
\text { on projects that do not benefit me }\end{array}$ & $33.9 \%$ & $21.4 \%$ & $44.6 \%$ \\
\hline 9 & $\begin{array}{c}\text { Tax evasion is ethical even if a large portion of the money collected is } \\
\text { spent on projects that do benefit me }\end{array}$ & $32.1 \%$ & $16.1 \%$ & $51.8 \%$ \\
\hline 10 & Tax evasion is ethical if everyone is doing it & $40.0 \%$ & $12.7 \%$ & $\mathbf{4 7 . 3 \%}$ \\
\hline 11 & $\begin{array}{l}\text { Tax evasion is ethical if a significant portion of the money collected } \\
\text { winds up in the pockets of corrupt politicians or their families and } \\
\text { friends }\end{array}$ & $54.5 \%$ & $23.6 \%$ & $21.8 \%$ \\
\hline 12 & Tax evasion is ethical if the probability of getting caught is low & $35.2 \%$ & $18.5 \%$ & $46.3 \%$ \\
\hline 13 & $\begin{array}{l}\text { Tax evasion is ethical if some of the proceeds go to support a war that I } \\
\text { consider to be unjust }\end{array}$ & $42.9 \%$ & $28.6 \%$ & $28.6 \%$ \\
\hline 14 & Tax evasion is ethical if I can't afford to pay & $48.1 \%$ & $22.2 \%$ & $29.6 \%$ \\
\hline 15 & $\begin{array}{l}\text { Tax evasion is ethical even if it means that if I pay less, others will have } \\
\text { to pay more }\end{array}$ & $35.7 \%$ & $17.9 \%$ & $46.4 \%$ \\
\hline 16 & Tax evasion would be ethical if I were a foreigner/ am not from Dessie & $39.3 \%$ & $12.5 \%$ & $48.2 \%$ \\
\hline 17 & $\begin{array}{l}\text { Tax evasion is ethical if the government discriminates against me } \\
\text { because of my religion }\end{array}$ & $44.4 \%$ & $16.7 \%$ & $38.9 \%$ \\
\hline 18 & $\begin{array}{l}\text { Tax evasion is ethical if the government imprisons people for their } \\
\text { political opinions/Religion affiliation }\end{array}$ & $48.2 \%$ & $17.9 \%$ & $33.9 \%$ \\
\hline
\end{tabular}

Source: survey result, 2015 
Table 13. Statement which are Never or almost never ethical and their rank

\begin{tabular}{|c|c|c|c|}
\hline S\# & Tax evasion is ethical even if most of the money collected is spent wisely & \%ank Never or almost never ethical (6 \&7) & $\mathbf{1}$ \\
\hline 5 & $\mathbf{5 1 . 8} \%$ & $\mathbf{4 2 . 9 \%}$ \\
\hline 6 & $\begin{array}{c}\text { Tax evasion is ethical if a large portion of the money collected is spent on projects that } \\
\text { I morally disapprove of }\end{array}$ & $\mathbf{8}$ \\
\hline 7 & $\begin{array}{c}\text { Tax evasion is ethical even if a large portion of the money collected is spent on worthy } \\
\text { projects }\end{array}$ & $\mathbf{5 0 . 0 \%}$ \\
\hline 8 & $\begin{array}{c}\text { Tax evasion is ethical if a large portion of the money collected is spent on projects that } \\
\text { do not benefit me }\end{array}$ & $\mathbf{7}$ & $\mathbf{4 4 . 6 \%}$ \\
\hline 9 & Tax evasion is ethical even if a large portion of the money collected is spent on & $\mathbf{5 1 . 8 \%}$ \\
\hline 10 & Tax evasion is ethical if everyone is doing it & $\mathbf{4}$ \\
\hline 12 & Tax evasion is ethical if the probability of getting caught is low & $\mathbf{5}$ \\
\hline 15 & Tax evasion is ethical even if it means that if I pay less, others will have to pay more & $\mathbf{4 6 . 3 \%}$ \\
\hline 16 & Tax evasion would be ethical if I were a foreigner/ am not from Dessie & $\mathbf{4 6 . 4 \%}$ \\
\hline
\end{tabular}

Source: The survey result, 2015

Table 14. Statements that are always or almost always ethical

\begin{tabular}{|c|c|c|c|}
\hline S\# & Statements & $\%$ always or almost always ethical (1 \& 2) & Rank \\
\hline 1 & Tax evasion is ethical if tax rates are too high & $44.4 \%$ & 6 \\
\hline 2 & $\begin{array}{l}\text { Tax evasion is ethical even if tax rates are not too high because the government is not } \\
\text { entitled to take as much as it is taking from me }\end{array}$ & $41.1 \%$ & 8 \\
\hline 3 & Tax evasion is ethical if the tax system is unfair & $50.0 \%$ & 2 \\
\hline 4 & Tax evasion is ethical if a large portion of the money collected is wasted & $44.6 \%$ & 5 \\
\hline 13 & $\begin{array}{c}\text { Tax evasion is ethical if some of the proceeds go to support a war that I consider to be } \\
\text { unjust }\end{array}$ & $42.9 \%$ & 7 \\
\hline 14 & Tax evasion is ethical if I can't afford to pay & $48.1 \%$ & 4 \\
\hline 17 & $\begin{array}{l}\text { Tax evasion is ethical if the government discriminates against me because of my } \\
\text { religion }\end{array}$ & $44.4 \%$ & 6 \\
\hline
\end{tabular}

Source: survey result, 2015

\subsubsection{Statements for Which Tax Evasion Is Never or Almost Never Ethical}

In some situation evading tax is objectionable even by taxpayers themselves. The table below ranks these situations from the highest to lowest level opposition of evading tax.

Table 13 summarizes the ranks of statements based up on "never or almost never" ethical viewpoint percentages. Accordingly, the statement having the largest degree of support for the "never or almost never" ethical viewpoint are S\# 9 and, S\# 5 and followed by S\# 7, S\#16, S\#10 and S\#12 respectively.

\subsubsection{Statements for which Tax Evasion is Always or Almost Always Ethical}

In some situation evading tax is acceptable in the view of taxpayers. The table below ranks these situations from the highest to lowest level support of evading tax.

Table 14 demonstrates the ranks of statements based up on "always or almost always" ethical view point percentages. Accordingly, the statement having the largest degree of support for the "“always or almost always" ethical viewpoint are S\# 11 and followed by S\# 3, S\# 18, S\# 14 and S\# 4 respectively. I.e the largest majority of 1 or 2 responses were for statement 11 , which had $54.5 \%$ of the total responsesTax evasion is ethical if a significant portion of the money collected winds up in the pockets of corrupt politicians or their families and friends. Thus, corruption provides a very strong justification for evading taxes for a large majority of the population. The second highest score in the "always or almost always" category was statement 3 , which had $50 \%$ of the total responses-Tax evasion is ethical if the tax system is unfair. Thus, unfairness provides a very strong justification next to corruption for evading taxes for a large majority of the population. Likewise, the government discrimination towards people against their political affiliation, unaffordable tax amount, unjust use the money collected government discrimination against taxpayers' religion etc take their role in justifying tax.

\section{Conclusions and Recommendations}

\subsection{Conclusions}

This study surveyed the tax evasion opinions of self-employed taxpayers in Dessie town administration. The 
study found out that, however, there is a widespread ethical support for tax evasion; in general, it can be concluded that tax evasion is sometimes ethical and sometime unethical in the point of view of taxpayers. In certain situation it is always ethical for taxpayers to evade tax and in some other situation it is never ethical to evade tax. Taxpayers believe that tax evasion is ethical when there is high tax rates, unfair tax system, when a large portion of the money collected is wasted, corruption, government discrimination against taxpayers religion, when the government imprisons people for their political opinions, unaffordable amount to pay and for other reasons. In the other way tax evasion is unacceptable in the view of taxpayers if the money collected is spent wisely, and on worthy projects, if a large portion of the money collected is spent on projects regardless that do benefit them or not. And taxpayers also believe evading tax is unethical even though it is everyone act and probability of getting caught is low. Furthermore, respondents believe that it is not ethical to evade tax even when large portion of the money collected is spent on projects that they morally disapprove of. So for Self-employed taxpayers' tax evasion is morally acceptable when the government was corrupt, the tax system was unfair and unaffordable. Those are the strongest arguments for tax evasion. Act with selfish motives of people to justify the tax evasion is seen as the weakest argument like evading tax when money spent wisely

These arguments clarifies that taxpayers have some perceptual reasons for tax evasion. The study finds out that the strongest perceptual reasons for tax evasion are the cases where a significant portion of the money collected winds up in the pockets of corrupt politicians or their families and friends, when the tax system is unfair, when the government imprisons people for their political opinions/Religion affiliation, when taxpayers can't afford to pay, while a large proportion of tax collected is wasted and in other situations. In general, the top six (6) ranking arguments in justifying tax evasion and which have the mean score of below the average of the scale (agreement level) are; government corruption, unfair tax system, government discrimination against political affiliation, tax affordability, when a large portion of the money collected is wasted, high tax rate. This shows that the responsiveness of government in terms of accountability, human right treatment and optimal tax rate play a significant role in the payment of taxes by this group of taxpayers.

In contrary to justification for tax evasion, there are also situations that taxpayers avoid evading tax. The most opposition to tax evasion occurred in cases when most of the money collected is spent wisely, if a large portion of the money collected is spent on worthy projects, when a large portion of the money collected is spent on projects that do benefit me, when a large portion of the money collected is spent on projects that do not benefit me and if it means that if I pay less, others will have to pay more.

In general, Taxpayers' most widespread ethical justification for tax evasion are corruption, unfair tax system, the government discrimination towards people against their political affiliation, unaffordable tax amount, unjust use of the money collected, government discrimination against taxpayers' religion etc take their role in justifying tax.

This study was also carried out to investigate the perceptions of female and male self-employed taxpayers towards ethics on tax evasion. Results suggest that female self employed taxpayers' opinions were quite different to that of men self employed taxpayers' opinions. Female are more likely to oppose tax evasion than male i.e. female are more ethical than men. When male taxpayers justify tax evasion with different reason female opposes those tax evasion justifications of male. In fact, a closer examination of the statements indicate that both groups believe that corruption and unfair tax system may somewhat justify tax evasion. In addition, both groups agree that if large portion of the money collected is spent on worthy projects, these are not good reasons to evade tax payments. Likewise, this study confirmed that educated self-employed taxpayers oppose tax evasion than uneducated.

The other intention of this study was to investigate tax evasion situation in Dessie town administration, hence, the study discovered that there is tax evasion culture among taxpaying community in Dessie. Only few people report all of their income to tax Authority. Due to that as taxpayers believe the government is losing more than $10 \%$ of the tax due to tax evasion. In the city, deliberate tax evasion is on the increase because significant proportion believes that tax evasion is a minor crime. In fact, on contrary, surprisingly taxpayers understand that it is their civic responsibility to pay his or her correct taxes. Not only that they also perceive it is not acceptable to evade tax in the society. In general some of the reason to evade tax in the study area are: people think they pay too much tax on what they earn already, The taxes collected are used poorly, There is a culture of tax evasion in Dessie everyone who has the opportunity to evade tax does so, and the risk of getting caught is low.

\subsection{Recommendation}

Based up on the finding of this study the following recommendation are forwarded

\subsubsection{Policy Recommendation}

- Among the leading justifications for the taxpayers to evade tax are corruption, discrimination against taxpayers' religion as well as discrimination of the people against their political affiliation and other administrative gaps of the government. Hence, the government should aware the society that the administration of the government are accountable and transparent for the society to increase tax collection or reduce tax evasion act

- The finding of this study indicated that citizens are very sensitive on how money collected is used wisely. And the study found out that under such act of the government taxpayers justify their tax evasion behavior. Therefore, government must change the perceptions of 
the society, particularly the taxpaying citizens about the issue in order to minimize tax evasion.

- The other significant justification for taxpayers' to evade tax is unfair tax system. This develops the tax evasion behavior of the taxpayers. To increase the tax paying rate, therefore, the government should develop a fair taxing system and also pay significant role in confirming that the tax system is fair to all taxpayers. In the government it is needed to reduce the perceived unfairness of the tax system

- Furthermore, this study investigated that the majority of the respondents believe that the probability of being caught is low in Dessie town. Taxpayers will not be caught if they evade tax. This indicated that the tax authority is expected to improve its enforcements.

- Likewise, educated taxpayers oppose tax evasion than uneducated. Hence, to reduce tax evasion behaviour or increase tax payment in the town, the government should encourage business man to be educated.

\subsubsection{Future Research Directions}

- It is also the researcher strong recommendation for future researchers that this study may be replicated in varies group of society, in different region of the country as well as in country wide to understand the ethics of tax evasion in the country and provide wide policy recommendations.

- This study describes the opinion of tax evasion only on academic status, and gender demography. Hence future researches can describe the perception of tax evasion in different demographics of the respondents.

\section{REFERENCES}

[1] Cullis, J., Jones, P. and Lewis, A., 2006. Tax framing, instrumentality and individual differences

[2] Fagbemi O T., Uadiale O. F and Noah O A. (2010). The Ethics of Tax Evasion: Perceptual Evidence from Nigeria. European Journal of Social Sciences - Volume 17, Number 3

[3] Adebisi, J. F, and Gbegi, D.O. (2013). Effect of Tax Avoidance and Tax Evasion on Personal Income Tax Administration in Nigeria. American Journal of Humanities and Social Sciences. Vo1. 1, No. 3, 125-134. DOI: $10.11634 / 232907811301328$

[4] Muhrtala T and, Ogundeji M. (2013). Professionals' Perspective of Tax Evasion: Some Evidence from Nigeria Universal Journal of Accounting and Finance 1(2): 35-41, DOI: $10.13189 /$ ujaf.2013.010201

[5] Devos, K. (2008). Tax Evasion Behavior and Demographic Factors: An Exploratory Study in Australia, Review Law Journal, 18(1), pp. 1-43

[6] Tilahun A. and Yidersal D . (2014). Determinants of Tax Compliance Behavior in Ethiopia: The Case of Bahir Dar City Taxpayers. Journal of Economics and Sustainable Development. ISSN 2222-1700 (Paper). Vol.5, No.15
[7] Asamnew Gebreselassie'. (2006).Tax assessment and collection problems of Category "A" taxpayers: A case of Yeka Sub City. A master thesis, Addis Ababa University Department of Accounting and Finance

[8] Fjeldstad H O., Chambas G and Brun FJ. (2014). Local government taxation in Sub-Saharan Africa: A review and an agenda for research.

[9] McKerchar, M. \& C. Evans 2009. Sustaining growth in developing economies through improved taxpayer compliance: Challenges for policy makers and revenue authorities eJournal of Tax Research, 7, 171-201

[10] Ali M, Fjeldstad O and Sjursen H I. (2013). To Pay or Not To Pay? Citizens' Attitudes Towards Taxation In Kenya, Tanzania, Uganda And South Africa. Working Paper No. 143. www.afrobarometer.org.

[11] Chiumya C. (2006).Counteracting Tax Evasion In Malawi: An Analysis Of The Methods And A Quest For Improvement. International Graduate School of Social Sciences. Online at http://mpra.ub.uni-muenchen.de/9892/

[12] Franzoni A.(1999)------- Tax Evasion And Tax Compliance .University of Bologna, Italy

[13] McGee W R, Aljaaidi S K, \& Musaibah S A. (2012). The Ethics of Tax Evasion: A Survey of Administrative Sciences' Students in Yemen. International Journal of Business and Management; Vol. 7, No. 16.

[14] McGee W R, Nickerson I, and Fees W. (2005). When is Tax Evasion Ethically Justifiable? A Survey of German Opinion. Proceedings of the Academy of Legal, Ethical and Regulatory Issues, Volume 9, Number 2

[15] McGee W R., Yoon Y. and Li Y. (2014). The Ethics of Tax Evasion: A Comparative Study of Chinese and U.S.Opinions. The Indonesian Journal of International \& Comparative Law ISSN: 2338-7602; E-ISSN: 2338-770X. The Institute for Migrant Rights Press

[16] Sezgin S, Yldz S, Ayyildiz Y. (2011). The Ethics of Tax Evasion: A Comparative Study of Turkey and Kyrgyzystan. Journal of Applied Business and Economics vol. 12(3)

[17] Kirchler, E. (2012). The economic psychology of tax behavior. Cambridge University press

[18] Murphy K. (2008). Enforcing Tax Compliance: To Punish or Persuade? Economic Analysis \& Policy, Vol. 38 No. 1

[19] Uadiale M O, Fagbemi O T, OgunleyeO J. (2010). An Empirical Study of the Relationship between Culture and Personal Income Tax Evasion in Nigeria. European Journal of Economics, Finance and Administrative Sciences . ISSN 1450-2275 Issue 20

[20] Harun J R., Abu Bakar J M., and Tahir M I. (2011). Ethics on Tax Evasion: Do Accounting and Business Students' Opinions Differ? /International Business and Management Vol.2 No.1

[21] Netsanet Bibisso (2014). Assessment Of Tax Audit Practice: The Case Of Hawassa City Administration.

[22] Palil R M. (2005). Taxpayers Knowledge: A Descriptive Evidence on Demographic Factors in Malaysia. Jurnal Akuntansi \& Keuangan, Vol. 7, No. 1, 11- 21

[23] Bruce . (2002). "Effects of the United States Tax System onTransitions Into Self-Employment." Labour Economics 
[24] Denscombe, M., 2003. "The Good Research Guide: For Small-scale Social Research Projects", $2^{\text {nd }}$ Ed., Maidenhead-Philadelphia: Open University Press

[25] McGee W R., Simon S., Ho M, and Li Y. (2006). A Comparative Study on Perceived Ethics Of Tax Evasion: Hong Kong Vs The United States

[26] Mc Gee robert (2008). opinoins on tax evasion in thiland. Taxation and public finance in transition and developing economies

[27] Gupta R and McGee R. (2010). Study on tax evasion perceptions in Australasia. Australian Tax Forum

[28] Richardson G. (2004). 'An Exploratory Study of Taxpayers' Perceptions of Fairness of the Hong Kong Tax System'. New Zealand Journal of Taxation Law and Policy
[29] Richardson M and Sawyer A. J. (2001). 'A Taxonomy of the Tax Compliance Literature: Further Findings Problems and Prospects.' Australian Tax Forum.

[30] Eicher J.D, Thomas J.S. and Wendy L.S. (2002) 'Men, Women, Taxes and Ethics', Tax Notes 401-406

[31] Mc Gee R. and Djatej A. (2007). The ethics of tax evasion: A survey of Hispanic opinion

[32] McGee R. \& Rossi M., (2006)The Ethics of Tax Evasion: A Survey of Law and Business Students in Argentina

[33] McGee R. and Yuhua A. (2007). An Empirical Study of Tax Evasion Ethics in China. Andreas School of Business Working Paper Series

[34] Karlinsky S., Burton H., \& Blanthorne C., (2004) Perceptions of Tax Evasion as a Crime. eJournal of Tax Research, Vol. 2, No. 2, 2004 